\title{
Upstream Regulators and Downstream Effectors of NADPH Oxidases as Novel Therapeutic Targets for Diabetic Kidney Disease
}

\author{
Yves Gorin*, and Fabien Wauquier
}

\begin{abstract}
Oxidative stress has been linked to the pathogenesis of diabetic nephropathy, the complication of diabetes in the kidney. NADPH oxidases of the Nox family, and in particular the homologue Nox4, are a major source of reactive oxygen species in the diabetic kidney and are critical mediators of redox signaling in glomerular and tubulointerstitial cells exposed to the diabetic milieu. Here, we present an overview of the current knowledge related to the understanding of the role of Nox enzymes in the processes that control mesangial cell, podocyte and tubulointerstitial cell injury induced by hyperglycemia and other predominant factors enhanced in the diabetic milieu, including the reninangiotensin system and transforming growth factor $\beta$. The nature of the upstream modulators of Nox enzymes as well as the downstream targets of the Nox NADPH oxidases implicated in the propagation of the redox processes that alter renal biology in diabetes will be highlighted.
\end{abstract}

\section{INTRODUCTION}

Oxidative stress plays a critical role in the initiation and development of diabetic nephropathy (DN) (Baynes, 1991; Forbes et al., 2008; Giacco and Brownlee, 2010; Hinokio et al., 1999; Kashihara et al., 2010; Schnackenberg, 2002; Singh et al., 2011; Son et al., 2004; Stanton, 2011). Diabetes is associated with an increase in generation of reactive oxygen species (ROS) in the glomerular and tubulointerstitial compartments of the kidney (Forbes et al., 2008; Kanwar et al., 2008; 2011; Kashihara et al., 2010; Koya et al., 2003; Singh et al., 2011; Stanton, 2011; Vasavada and Agarwal, 2005). Although chronic hyperglycemia is sufficient to promote renal cell injury, data from experimental animal models as well as cultured cells indicate that a combination of growth factors, hormones and cytokines, in addition to high

Department of Medicine, University of Texas Health Science Center, San Antonio, Texas, USA

${ }^{*}$ Correspondence: gorin @uthscsa.edu

Received 9 January, 2015; acceted 12 January, 2015; published online 31 March, 2015

Keywords: diabetic nephropathy, downstream effectors of Nox NADPH oxidases, Nox family of NADPH oxidases, oxidative stress, upstream regulators of Nox NADPH oxidases glucose concentrations, alter the redox status of the cells and contribute to cell damages in the diabetic kidney (Abboud, 1997; Campbell et al., 2011; Gorin and Block, 2013a; 2013b; Kanwar et al., 2008; 2011; Kashihara et al., 2010; Rincon-Choles et al., 2002; Singh et al., 2011). While multiple pathways lead to ROS generation, i.e., mitochondrial electron transport chain, xanthine oxidase or uncoupled nitric oxide synthase, recent evidence demonstrates that the Nox family of NADPH oxidases constitutes a major source of ROS in nonphagocytic cells, including renal cells (Ago et al., 2010; Barnes and Gorin, 2011; Bedard and Krause, 2007; Block et al., 2009; Brown and Griendling, 2009; Brownlee, 2005; Coughlan et al., 2009; Craven et al., 2001; Dikalov, 2011; Gill and Wilcox, 2006; Gorin and Block, 2013a; 2013b; Gorin et al., 2005; Griendling and FitzGerald, 2003; Hwang et al., 2012; Kiritoshi et al., 2003; Kitada et al., 2011; Lambeth, 2007; Lambeth et al., 2007; Lassegue and Clempus, 2003; Lassegue and Griendling, 2010; Lassegue et al., 2012; Nishikawa et al., 2000; Octavia et al., 2012; Paravicini and Touyz, 2008; Rivera et al., 2010; Sedeek et al., 2012). The present review will focus on the upstream regulators controlling the expression and activity of the Nox enzymes as well as the downstream effectors targeted by Nox-derived ROS to initiate and propagate diabetes-induced glomerular and tubulointerstitial cell injury.

\section{NADPH OXIDASES OF THE NOX FAMILY PREDOMINANTLY EXPRESSED IN THE KIDNEY}

To date, the Nox family comprises seven members: Nox1-5, and the dual oxidases (Duox) Duox1 and -2 (Bedard and Krause, 2007; Geiszt, 2006; Lambeth et al., 2007; Selemidis et al., 2008). Nox4, Nox1, Nox2 (a.k.a. gp91phox), and Nox5 are the Nox homologues that are predominantly expressed in glomerular cells (mesangial cells, glomerular epithelial cells or podocytes), glomerular endothelial cells and tubulointerstitial cells (tubular epithelial cells and interstitial fibroblasts) (Gorin and Block, 2013a; 2013b). These Nox homologues consist of six membrane-spanning regions with binding sites for NADPH, flavin adenine dinucleotide (FAD), and heme. The latter comprise electron transfer centers that pass electrons from NADPH to oxygen forming superoxide $\left(\mathrm{O}_{2}{ }^{-}\right)$and hydrogen peroxide $\left(\mathrm{H}_{2} \mathrm{O}_{2}\right)$ (Bedard and Krause, 2007; Brown and Griendling, 2009; Geiszt, 2006; Geiszt et al., 2000; Gorin and Block, 2013a; Lassegue and Griendling, 2010; Lassegue et al., 2012; Selemidis et al., 2008; Shiose et al., 2001). The calciumdependent homolog Nox5 is found in the human kidney tissue 
Regulators and Effectors of Nox Oxidases in Diabetic Nephropathy Yves Gorin \& Fabien Wauquier

and cells, but is not present in mice and rats (Brandes et al., 2010; Lassegue and Griendling, 2010).

The isoforms Nox2 and Nox1 require p22phox as an activating, stabilizing and/or regulatory subunit for binding to p47phox or NoxO1 (Bedard and Krause, 2007; Geiszt, 2006; Selemidis et al., 2008). Activation mechanisms for Nox1 are similar to those of Nox2, and involve complex formation with regulatory subunits upon agonist stimulation. Although Nox1 seems to primarily interact with the p47phox homolog NoxO1 (Nox organizer 1), the p67phox homolog NoxA1 (Nox activator 1), and small GTPase Rac upon activation, it was reported that p47phox and p67phox can partially replace NoxO1 and NoxA1, respectively (Bedard and Krause, 2007; Brandes and Schroder, 2008; Brandes et al., 2010; Geiszt, 2006; Lambeth, 2007; Lassegue and Griendling, 2010; Selemidis et al., 2008;). Nox4 heterodimerization with p22phox enhances the enzyme activity but the oxidase does not required the regulatory subunits essential to other Nox isoforms and is a constitutively active enzyme regulated primarily at the level of its expression in response to various stimuli, including mediators of DN such as high glucose (HG) (Block et al., 2009; Eid et al., 2009; 2013b) transforming growth factor- $\beta$ (TGF- $\beta$ ) (Bondi et al., 2010; Cucoranu et al., 2005), angiotensin II (Ang II) (Block et al., 2008), insulin, insulin-like growth factor (IGF-I), and advanced glycation end products (AGEs) or advanced oxidation protein products (AOPPs) (Bedard and Krause, 2007; Lassegue and Clempus, 2003; Lassegue and Griendling, 2010; Lassegue et al., 2012; Lee et al., 2013a; Mahadev et al., 2004; Meng et al., 2008; Menini et al., 2007; New et al., 2012; Selemidis et al., 2008; Thallas-Bonke et al., 2008). As a consequence, the overall ROS output of Nox4 is directly governed by its expression level. Importantly, it is suggested that transcriptional events are implicated in the chronic control of Nox4 protein expression (Chai et al., 2008; Cucoranu et al., 2005; Eid et al., 2009; 2010; 2013a; Hecker et al., 2009; Moe et al., 2006; Mittal et al., 2007; Pedruzzi et al., 2004; Serrander et al., 2007; Wingler et al., 2001; Yamagishi et al., 2005), whereas acute regulation of Nox4 occurs via translational mechanisms without change in its mRNA levels (Block et al., 2008; 2009; Bondi et al., 2010; Meng et al., 2008; New et al., 2012; Peshavariya et al., 2009). Regulatory proteins that enhance Nox4 activity like polymerase delta-interacting protein 2 (Poldip2) and the p47phox-related adaptor protein, Tks (tyrosine kinase substrate with five $\mathrm{SH} 3$ domains) 5 , have recently been identified (Diaz et al., 2009; Lyle et al., 2009; Sedeek et al., 2009). A potential implication of Rac in the control of Nox4 function was suggested in endothelial and mesangial cells (Chai et al., 2008; Gorin et al., 2003; Wu et al., 2007); however, it remains a controversial topic because, unlike Nox2 or Nox1, Rac1 does not activate Nox4 in transfected cells (Bedard and Krause, 2007). The activity of Nox5 is not controlled by any other subunits and is strictly dependent on calcium binding to the enzyme through its EF hand domains (Bedard and Krause, 2007).

It is important to mention that Nox4 seems to produce a higher hydrogen peroxide to superoxide ratio than Nox1, Nox2 and Nox5. Recent studies strongly suggest that hydrogen peroxide formation occurs through Nox4 third extracytosolic loop (E-loop) and that the structure of the E-loop may obstruct superoxide release as well as provide a source for protons, thus permitting rapid dismutation of superoxide to generate hydrogen peroxide (Takac et al., 2011). Although Nox4 predominantly produces hydrogen peroxide, numerous studies in vascular or renal cells and tissue detected Nox4-dependent superoxide production (Ago et al., 2010; Block et al., 2009;
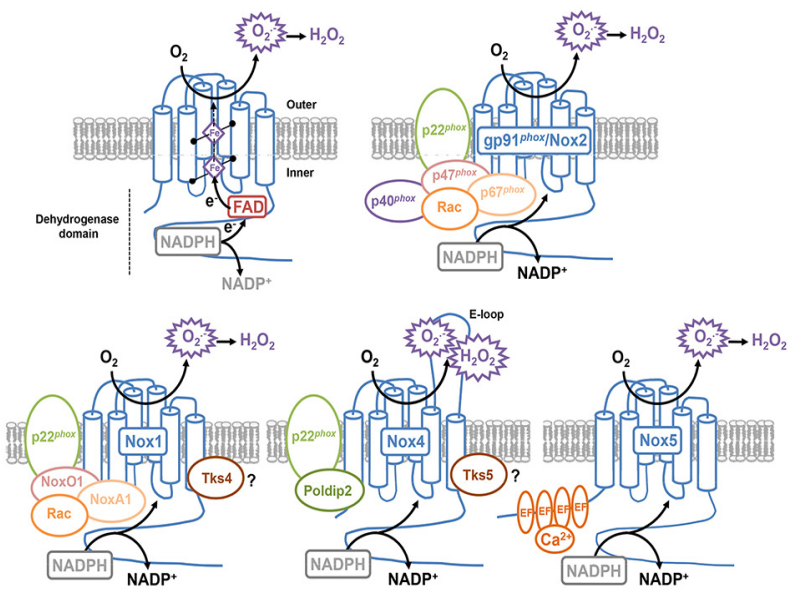

Fig. 1. Structure and molecular organization of the renal Nox NADPH oxidases. The top right left panel illustrates the topology of and the enzymatic reaction catalyzed by the Nox enzymes. The other panels represent the molecular structure of the Nox oxidase homologues predominantly expressed in the kidney, Nox2 (a.k.a. gp91phox), Nox1, Nox4, and Nox5. The regulatory subunits differ from a Nox homologue to another.

Clempus et al., 2007; Cucoranu et al., 2005; Eid et al., 2009; 2010; Gorin et al., 2005; Kuroda et al., 2005; 2010; Liu et al., 2010; Maalouf et al., 2012; Peshavariya et al., 2007; Shiose et al., 2001). Figure 1 shows the structure and molecular organization of the renal Nox NADPH oxidases.

\section{UPSTREAM REGULATORS AND DOWNSTREAM EFFECTORS OF NOX NADPH OXIDASES IN DIABETES- INDUCED GLOMERULAR MESANGIAL CELL INJURY}

The importance of Nox4 in mesangial cell injury is supported by studies in experimental rodent models of diabetes as well as in vitro work in cultured cells exposed to HG. Nox4 protein expression increases in the glomeruli, including the mesangium, and Nox4-derived ROS contribute to oxidative stress during the initial and chronic stages of diabetes (Eid et al., 2009; 2010; Etoh et al., 2003; Fujii et al., 2007; 2010; Gorin et al., 2005; Maeda et al., 2010; Sonta et al., 2005). The elevation in Nox4 protein and ROS generation are reversed by insulin treatment, confirming that hyperglycemia and hyperglycemia-induced mediators are responsible for these effects (Etoh et al., 2003; Gorin et al., 2005). Our group provided the initial evidence that Nox4-dependent ROS generation mediates glomerular hypertrophy and mesangial matrix accumulation (Gorin et al., 2005). We showed that inhibition of Nox4 oxidase by administration of antisense oligonucleotides for Nox4 significantly reduced glomerular enlargement as well as fibronectin accumulation in glomeruli from type 1 diabetic rats (Gorin et al., 2005). Recent studies using ApoE/Nox4 double knockout mouse or Nox4 knockout mice on C57BL6/J background made type 1 diabetic with streptozotocin showed that genetic deletion of Nox4 markedly attenuated diabetes-induced oxidative stress, mesangial matrix expansion as well as extracellular matrix protein fibronectin and collagen IV accumulation in the glomeruli (Jha et al., 2014; Thallas-Bonke et al., 2014). It should be mentioned that both Nox4 and Nox5 expression are increased in human 
diabetic glomeruli (Holterman et al., 2014).

In cultured mesangial cells, glucose elicits a rapid upregulation in Nox4 protein levels, including in the mitochondrial fraction, which is associated with an increase in cellular and mitochondrial ROS production (Block et al., 2009; Eid et al., 2013b; Papadimitriou et al., 2014; Shah et al., 2013). Moreover, prolonged exposure of mesangial cells to $\mathrm{HG}$ has also been described to augment Nox4 mRNA and protein expression (Etoh et al., 2003; Fu et al., 2010; Jeong et al., 2012). Nox4 is required for $\mathrm{HG}$-induced (acute or chronic) increase in ROS production and accumulation of fibronectin in these cells (Gorin et al., 2005). Furthermore, Nox4 participates to HG-mediated mitochondrial ROS generation in mesangial cells (Block et al., 2009), suggesting that Nox4-derived ROS may affect mitochondrial function. This contention is supported by the recent observation that ROS generated by overexpression of Nox4 are able to oxidize and affect the activity of mitochondrial proteins in cardiac myocytes (Ago et al., 2010). Moreover, Nox4derived ROS have been reported to decrease mitochondrial function via disruption of complex I in endothelial cells (Koziel et al., 2013). These findings suggest that mitochondrial electron transport chain may be a downstream effector of Nox4. A short paracrine loop may exist, by which ROS production by mitochondrial Nox4 alters mitochondrial respiratory chain activity, thereby leading to more ROS generation by the dysfunctional mitochondrial electron transport chain and alteration of mitochondrial function.

Recent work from our group identified important downstream targets of Nox4-derived ROS in the pathway linking HG to mesangial cell fibrotic injury (Eid et al., 2013b). The study revealed the role of Nox4 as a critical mediator of endothelial nitric oxide synthase (eNOS) uncoupling and decrease in nitric oxide (NO) bioavailability induced by $\mathrm{HG}$ in cultured mesangial cells and in diabetes in vivo (Eid et al., 2013b). We demonstrate that ROS derived from dysfunctional eNOS contribute to fibronectin expression in mesangial cells exposed to $\mathrm{HG}$. The molecular mechanisms underlying this process involve the reaction of Nox4-derived superoxide with $\mathrm{NO}$ generated constitutively by functional eNOS resulting in the formation of peroxynitrite that subsequently uncouples eNOS, further promoting superoxide generation (Eid et al., 2013b). In the diabetic milieu, Nox4-dependent eNOS uncoupling, not only eliminates the protective effect of eNOS-derived NO, but also converts the enzyme to a phlogistic mediator that further enhances ROS generation and mesangial cell fibrotic response. A role for Nox4 in peroxynitrite production and NOS (eNOS or neuronal NOS) uncoupling have been confirmed in other systems (de Mochel et al., 2010; Ito et al., 2013; Siu et al., 2015) as well as in the diabetic kidney where Nox4 deletion reduced peroxynitrite production in the glomeruli (Jha et al., 2014; Thallas-Bonke et al., 2014). Protein kinase $C$ (PKC) is also a downstream target of Nox4 in diabetic glomeruli. This is supported by the findings that the major isoforms of PKC that are increased with diabetes in the glomeruli can be normalized in Nox4 knockout mice (Thallas-Bonke et al., 2014).

Novel upstream regulators of Nox4-dependent ROS generation were also recently characterized. We demonstrated that Sestrin 2 attenuates HG-induced ROS generation and MC mesangial cell fibrotic injury through blockade of Nox4dependent eNOS dysfunction/decline in NO levels (Eid et al., 2013b). Specifically, Sestrin 2 counteracts Nox4-mediated ROS production via impeding the rapid upregulation of Nox4 protein elicited by HG. The stress-inducible protein Sestrin 2 is known to suppress ROS and protect cells from oxidative stress but the mechanisms by which Sestrin 2 exerts its antioxidant properties remain unclear. The characterization of Sestrin 2 as an upstream negative regulator of Nox4 unveiled a novel molecular mechanism by which Sestrin 2 is able to inhibit oxidative stress. Importantly, AMP-activated protein kinase (AMPK) functions as a mediator of Sestrin 2 inhibitory effects on HG-stimulated and Nox4-dependent eNOS dysfunction and extracellular matrix protein accumulation in mesangial cells (Eid et al., 2013b). The function of AMPK as a negative modulator of HG-mediated increase in Nox4 expression in mesangial cells is further supported by a recent report (Papadimitriou et al., 2014). It should be mentioned that the protective effects of Sestrin 2/AMPK is reciprocally blunted by $\mathrm{HG}$. Hence, $\mathrm{HG}$ promotes $\mathrm{AMPK}$ inactivation via downregulation of Sestrin 2 , which in turn results in increased Nox4 and Nox4-dependent ROS production followed by eNOS uncoupling and decrease in NO bioavailability and enhancement of mesangial cell fibrotic response (Eid et al., 2013b).

Other studies have demonstrated that statins and Rho kinase inhibitors prevent increased Nox4 expression and oxidative stress in diabetic kidney, including glomeruli, concomitantly to the amelioration of mesangial matrix expansion and renal function, indicate that small GTPases Rho and Rac pathways (known targets of statins) may act as upstream modulators of Nox4 expression and Nox4-dependent ROS release (Fujii et al., 2007; Gojo et al., 2007). microRNAs also play a role in Nox4 expression and serves as an endogenous silencer for Nox4 gene in mesangial cells (Fu et al., 2010). miR-25 seems to negatively regulate Nox4 expression by directly targeting its 3' untranslated region ( $\left.3^{\prime}-\mathrm{UTR}\right)$ (Fu et al., 2010). The downregulation of microRNA-25 (miR-25) by HG in mesangial cells or by hyperglycemia in diabetic kidney results in the relief of Nox4 gene silencing that lead to increased Nox4 expression and ROS production (Fu et al., 2010). Similar functional relationship between miR-25 and Nox4 was reported in the heart where downregulation of miR-25 results in increased Nox4 expression and subsequent oxidative and nitrative stress (Varga et al., 2013). Thioredoxin-interacting protein (TxNIP) has been recently identified as an upstream regulator of Nox4 protein expression in mesangial cells exposed to HG. TxNIP mediates HG-induced ROS generation by Nox4 in mesangial cells (Shah et al., 2013).

The mRNA and protein expression of p22phox, the subunit required for full activation of Nox4, are upregulated by glucose in mesangial cells as well as in glomeruli from diabetic animals (Maeda et al., 2010; Whiteside et al., 2009; Xia et al., 2006; Zhang et al., 2012). Interestingly, Nox4 and p22phox both contribute to HG-dependent oxidative stress and fibronectin or collagen IV accumulation as well as the expression of other markers of fibrotic injury in mesangial cells (Xia et al., 2006; 2008; Zhang et al., 2012). Equivalent to what is seen for Nox4, AMPK activation is also able to counteract the induction of ROS production by $\mathrm{HG}$ via blockade of a p22phox upregulation in mesangial cells (Whiteside et al., 2009). These observations are consistent with the concept proposing that AMPK act as a suppressor of oxidative stress via inhibition of NADPH oxidase subunits expression in various biological systems including vascular tissues (McCarty et al., 2009; Schuhmacher et al., 2011; Wang et al., 2010). Because it is known that p22phox interacts with Nox4 and enhances its activity, it is reasonable to think that in these cells, Nox4 and p22phox may form a complex that accounts for HG-induced ROS generation and the subsequent fibrotic response.

Nox4 also confers Ang II-mediated harmful effects in 
mesangial cells. Ang II elicits an acute increase in Nox4 protein expression as well as a chronic prolonged upregulation of Nox4 mRNA and protein levels associated with enhanced ROS production in these cells (Block et al., 2008; Fujii et al., 2010). Ang II also elicits an increase in mitochondrial abundance of Nox4 protein and the oxidase contributes to ROS production in mitochondria (Lee et al., 2013a). Ang Il-induced ROS generation in mesangial cells acts principally through Nox4 as an upstream activator of extracellular signal-regulated kinase 1/2 (ERK1/ ERK2), proline-rich tyrosine kinase-2 (Pyk-2)/Src/3-phosphoinositide-dependent protein kinase-1 (PDK-1), Akt/protein kinase $B(A k t / P K B)$, and/or p70 S6 kinase (p70S6K) pathways that lead to cell hypertrophy and increased protein synthesis and/or fibronectin expression (Barnes and Gorin, 2011; Block et al., 2008; Gorin et al., 2003; 2004). More specifically, Pyk-2 appears to act as a molecular scaffold binding to both PDK-1 and Src, thereby allowing Src to tyrosine phosphorylate and activate PDK-1, which in turn activate its downstream effectors, Akt/PKB and p70S6K (Block et al., 2008). Interestingly, PDK1/Src/Pyk-2 complex may favor the formation of signaling platforms bringing key intermediates into proximity, thereby facilitating the contact between Nox4-derived ROS and downstream effectors (Block et al., 2008; Ushio-Fukai, 2006). Importantly, the most proximal event physically tethering Nox4 activation by Ang II to the rest of the signaling cascade is a redox-dependent posttranslational modification of Src on cysteine residues induced by Nox4-derived ROS (Block et al., 2008). It was reported that activation of Rac1 by phospholipase $A_{2}\left(P L A_{2}\right)-$ mediated arachidonic acid $(A A)$ release appears to be implicated in Nox4-dependent ROS production and subsequent Akt/PKB-mediated cellular hypertrophy in mesangial cell treated with Ang II (Gorin et al., 2003; 2004). Our recent work also placed Nox4 as central mediator that control Ang II-induced redox signaling that lead to peroxynitrite-dependent eNOS dysfunction, decline in NO bioavailability and MC fibrotic injury (Lee et al., 2013a). The p22phox subunit is also required for the hypertrophic and fibrotic actions of Ang II in mesangial cells (Block et al., 2006).

Comparable to what was observed in a myriad of cell types (Barnes and Gorin, 2011; Bondi et al., 2010; Cucoranu et al., 2005), TGF- $\beta$ specifically increases the expression of Nox4 and ROS production in mesangial cells. Moreover, a role for Nox4 in TGF- $\beta$-mediated ROS generation and mesangial cell fibrotic injury was established (Jha et al., 2014; Papadimitriou et al., 2014). p22phox is required for TGF- $\beta$-induced ROS production in mesangial cells (Xia et al., 2008). As described above for HG, AMPK also acts as a negative regulator of TGF- $\beta$-dependent Nox4 upregulation and subsequent ROS production in these cells.

PKC isozymes are positioned upstream and downstream of p22phox-containing NADPH oxidases and ROS production in mesangial cells exposed to HG or TGF- $\beta$ (Kwan et al., 2005; Xia et al., 2006). Furthermore, in mesangial cells, HG-induced oxidative stress involves autocrine TGF- $\beta$ stimulation of PKC and resultant generation of ROS by p22phox-based Nox oxidase via p22phox protein upregulation (Xia et al., 2008). Other studies with mesangial cells exposed to AOPPs place an NADPH oxidase, distal to PKC activation, resulting in extracellular matrix protein overproduction and upregulation of TGF- $\beta$ (Wei et al., 2009).

The role of other Nox catalytic isoforms or regulatory subunits in mesangial cell injury in the diabetic kidney has been less studied. A role for Nox2 or Nox1 is indirectly suggested by the observation that administration of apocynin significantly re-

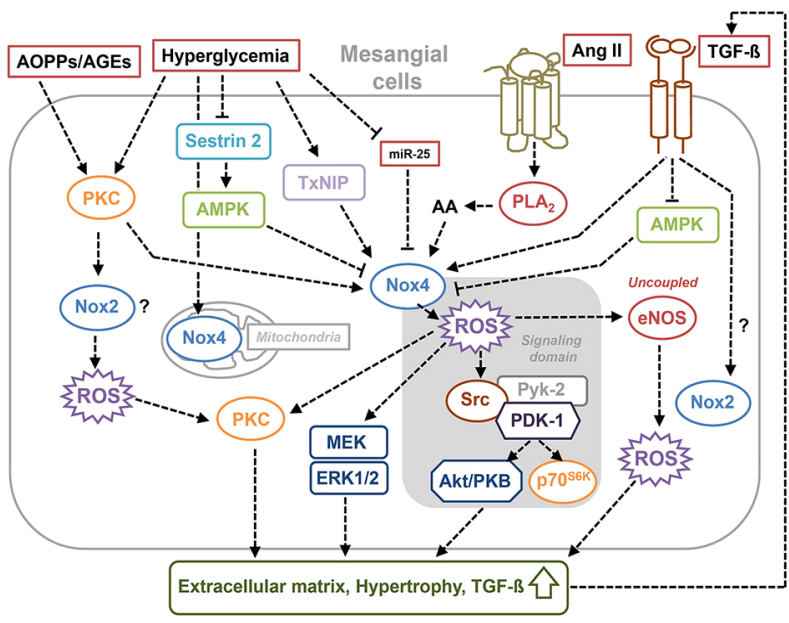

Fig. 2. Upstream and downstream effectors of Nox oxidases implicated in glomerular mesangial cell injury triggered by diabetic stimuli. See text for detail.

duced glomerular fibronectin and collagen accumulation in type 1 diabetic rats (Asaba et al., 2005). However, The involvement of Nox2 in the mesangium is not clear as some studies indicate that Nox2 is not detected in cultured human and rat mesangial cells whereas Nox2 is detected in isolated mouse mesangial cells and in diabetic glomeruli (Jones et al., 1995; Liu et al., 2012; Miyata et al., 2005). Nox2 regulatory subunits p47phox and p67phox are systematically found in mesangial cells (Jones et al., 1995; Pleskova et al., 2006) and the expression and translocation of p47phox and p67phox to the membrane is increased in the diabetic glomeruli (Kitada et al., 2003). HG causes an increase in p47phox protein expression in mesangial cells and downregulation of p47phox blunts high glucoseinduced ROS and extracellular matrix accumulation (Hua et al., 2003; Kwan et al., 2005; Xia et al., 2006). Importantly, diabetesinduced oxidative stress and glomerular injury are attenuated in p47phox-deficient type 1 diabetic Akita mice (Liu et al., 2012). Moreover, deletion of p47phox attenuates diabetes-induced and HG-induced Nox2 expression in glomeruli and mesangial cells, respectively (Liu, et al., 2012). This indicates that p47phox-dependent activation of Nox oxidase, likely Nox2, is determinant for the promotion of DN. However, a recent study showed that glomerular mesangial matrix expansion and albuminuria are not attenuated in type 1 diabetic Nox2 knockout mice (You et al., 2013). Interestingly, an upregulation of Nox4 is observed in these mice (You et al., 2013). Together, these findings warrant a reassessment of the role of Nox2 in DN. While Nox1 is thought to promote the deleterious effects of glucose or Ang II in the vasculature (Lassegue et al., 2001; Lavrentyev and Malik, 2009), its function in mesangial cell injury in the diabetic milieu has not been reported. Indeed, a role for Nox1 as a source of renal ROS and mediator of DN has been challenged by the recent report showing that deletion of Nox4, but not Nox1, in a mice model of type 1 diabetes in ApoE knockout mice resulted in renal protection from glomerular injury (Jha et al., 2014). However, p47phox and p67phox recruitment to the membrane contributes to Ang II-mediated oxidative stress and mesangial cell growth (Ding et al., 2007) and TGF- $\beta$ was reported to upregulate the expression of Nox2, p22phox, p47phox and p67phox in mesangial cells (Lee et al., 2003). 
AOPPs also increase p22phox, p47phox and Nox4 protein expression (Wei et al., 2009). AOPPs promote an increase in p47phox expression and translocation as well as its interaction with p22phox expression (Wei et al., 2009). These events are associated with enhanced extracellular matrix protein synthesis. Although PKC-dependent NADPH oxidase activation mediates AGEs-induced mesangial cell fibrotic injury (Thallas-Bonke et al., 2008), the Nox subunits implicated in these processes remain to be identified. In vivo studies suggested that induction of glomerular injury by AGEs is due to Src homology 2 domaincontaining transforming protein $\mathrm{C} 1$ (Shc1) isoform $\mathrm{p}^{\mathrm{Shc}}$. mediated Nox4 expression (Menini et al., 2007).

Figure 2 is an overview of the major redox pathways and signaling intermediates positioned upstream and downstream of Nox enzymes that are stimulated by diabetic stimuli to promote glomerular mesangial cell injury.

\section{UPSTREAM REGULATORS AND DOWNSTREAM EFFECTORS OF NOX NADPH OXIDASES IN DIABETES- INDUCED GLOMERULAR EPITHELIAL CELL/PODOCYTE INJURY}

Upregulation of Nox4 protein expression in diabetic glomeruli including podocytes is accompanied by increased oxidative stress, loss of podocyte or foot process effacement as well as albuminuria in OVE26 type 1 diabetic mice (Eid et al., 2009; 2010; 2013a; Khazim et al., 2013; Sharma et al., 2008). In cultured podocytes exposed to $\mathrm{HG}$ for prolonged time period, Nox4 mRNA and protein are augmented and Nox4-derived ROS play a key role in apoptotic cell death (Eid et al., 2009; 2010; 2013a; Jha et al., 2014; Khazim et al., 2013; Piwkowska et al., 2011; Sharma et al., 2008). In human podocytes where both Nox4 and Nox5 are present, HG had no effect on Nox5 mRNA expression but significantly increased Nox4 mRNA levels (Jha et al., 2014). Transgenic mice overexpressing human Nox5 in a podocyte-specific manner exhibited early onset of albuminuria and podocyte foot process effacement (Holterman et al., 2014). Subjecting the mice to streptozotocininduced type 1 diabetes further exacerbated these changes (Holterman et al., 2014).

A sequential regulation of Nox oxidases by cytochrome P450 of the 4A family (CYP4A) was recently identified in podocytes in which 20-hydroxyeicosatetraenoic acid (20-HETE) generation by CYP4A mediates the stimulatory effect of HG on Nox4 and Nox1 expression and the resultant ROS production at later time points (Eid et al., 2009). In the presence of HG concentrations, Nox4 promotes podocyte cell death via activation of p53- and PUMA-dependent apoptotic pathway (Eid et al., 2010). The oxidative stress triggered by $\mathrm{HG}$ appears to be exacerbated by the fact that the ROS generated by Nox4 affects the balance between oxidants and antioxidants by decreasing the activity of key antioxidant enzymes such as glutathione peroxidase (GPx) and catalase (Piwkowska et al., 2011). Importantly, inactivation of AMPK-activated protein kinase (AMPK) by HG accounts for the increase in Nox4 mRNA and protein expression as well as subsequent ROS production and podocyte apoptosis (Eid et al. 2010). AMPK activators, e.g. AICAR (5-aminoimidazole-4-carboxamide-1-riboside) or adiponectin, significantly reduced Nox4 expression, oxidative stress and podocyte injury in vitro or in vivo (Eid et al., 2010; Piwkowska et al., 2010; Sharma et al., 2008). A recent report indicates that mammalian target of rapamycin complex 1 (mTORC1) is an upstream positive regulator of Nox4 expression and subsequent ROS production and injury in podocytes exposed to HG or in vivo in glomeruli from

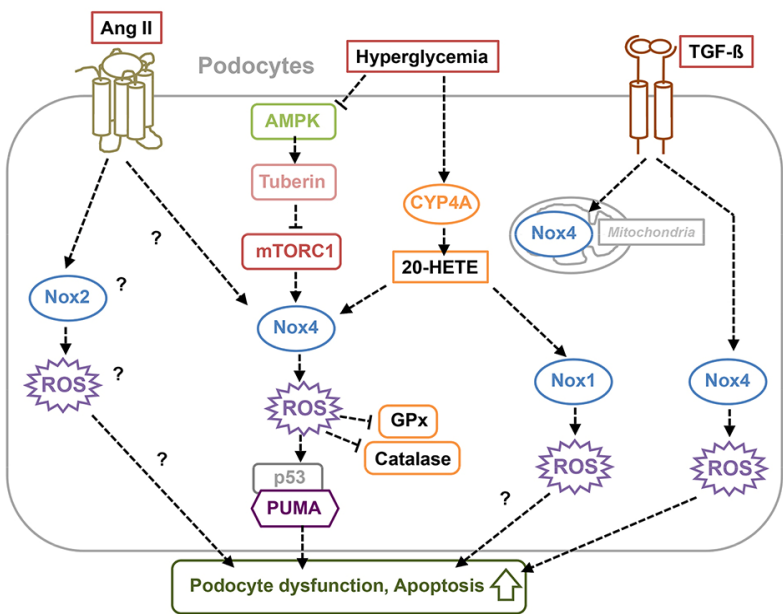

Fig. 3. Upstream and downstream effectors of Nox oxidases implicated in podocyte injury triggered by diabetic stimuli. See text for detail.

OVE26 type 1 diabetic mice (Eid et al., 2013a). The same report showed that AMPK exerts its protective actions by inhibiting mTORC1 pathway via tuberin activation (Eid et al., 2013a).

Although podocytes also express Nox2, p22phox, p47phox and p67phox (Greiber et al., 1998; Nistala et al., 2008), there is no evidence of regulation of these subunits by HG. Similar to Nox4, Nox1 protein levels are increased in glomeruli from OVE26 mice (Eid et al., 2009; 2010). Nox1 protein is upregulated by $\mathrm{HG}$ in cultured podocytes and, as for Nox4, mTORC1 positively regulates Nox1 expression (Eid et al., 2013a). While Ang II- or TGF- $\beta$-induced oxidative stress mediates podocyte injury (Campbell et al., 2011; Nistala et al., 2008; Ziyadeh and Wolf, 2008), very little is known regarding the role of the Nox oxidases in the podocyte dysfunction promoted by these agonists or the other major mediators of DN. Similar to what is observed in MCs, Ang II-dependent increase in NADPH oxidase activity is associated with the upregulation of Nox4, Nox2, Rac and p22phox expression in podocytes (Nistala et al., 2008; Whaley-Connell et al., 2008). Stimulation with Ang II upregulates Nox5 expression in human podocytes and Nox5 is required for Ang II-induced ROS production as well as altered podocyte cytoskeletal dynamics (Holterman et al., 2014). Nox4 was detected within the mitochondria in podocytes and a recent report suggested that TGF- $\beta$-induced mitochondrial Nox4 upregulation via the Sma and Mad homologue (Smad) 2/3 pathway is responsible for ROS production, mitochondrial dysfunction, and apoptosis in podocytes (Block et al., 2009; Das et al., 2014; Yu et al., 2014a). Note that in human podocytes, Nox5 mRNA expression is enhanced following treatment with TGF- $\beta$ (Jha et al., 2014).

Figure 3 is an overview of the major redox pathways and signaling intermediates positioned upstream and downstream of Nox enzymes that are stimulated by diabetic stimuli to promote glomerular mesangial cell and podocyte injury.

\section{UPSTREAM REGULATORS AND DOWNSTREAM EFFECTORS OF NOX NADPH OXIDASES IN DIABETES-INDUCED TUBULAR CELL INJURY}

Similar to glomeruli, tubules from type 1 diabetic rats show an 
increase in Nox4 mRNA and protein expression and downregulation of tubular Nox4 levels with in vivo administration of antisense oligonucleotides reduces diabetes-mediated ROS production and extracellular matrix protein synthesis in the renal cortex that is mainly composed of tubular epithelial cells (Etoh et al., 2003; Fujii et al., 2010; Gorin et al., 2005). The importance of Nox4 as a major source of ROS in the tubular compartment was further supported by a recent study in type 1 diabetic ApoE/Nox4 double knockout mice or Nox4 knockout mice on C57BL6/J background showing that Nox4 genetic deletion markedly reduced ROS production in renal cortex (Jha et al., 2014; Thallas-Bonke et al., 2014). Noteworthy, Nox4 was also shown to be responsible for diabetes-induced ROS production in mitochondria isolated from cortex (Jha et al., 2014). Importantly, the function of Nox1 as a generator of ROS in tubules is weakened by the observations that ROS production is not affected in the renal cortex of type 1 diabetic ApoE/Nox1 knockout mice (Jha et al., 2014). Interestingly, Nox4 protein expression is increased in renal cortex but is unchanged in medulla from type 2 diabetic mice (Sedeek et al., 2010). Increased Nox4 expression in diabetic tubules correlates with an augmentation in p22phox levels (Etoh et al., 2003; Sedeek et al., 2010). Whilst the levels of Nox2 and p47phox are not affected in renal cortex from type 2 diabetic mice (Sedeek et al., 2010), Nox2 is increased in the cortex from type 1 diabetic rats (Gorin et al., 2005). A role for Nox2 is challenged by a recent report showing that tubulointerstitial injury is not ameliorated in type 1 diabetic Nox2 knockout mice (You et al., 2013). Exposure of cultured renal proximal tubular epithelial cells to $\mathrm{HG}$ leads to the upregulation of Nox4 protein expression but seems to have no effect on Nox2, Nox1, p22phox or p47phox expression (Ford et al., 2013; Sedeek et al., 2010). Furthermore, Nox4-dependent ROS production is required for glucoseinduced increase in fibronectin accumulation and TGF- $\beta$ expression in these cells (Ford et al., 2013; Sedeek et al., 2010). The profibrotic action of the oxidase is corroborated by the finding that overexpression of Nox4 in tubular cells causes a robust increase in fibronectin synthesis (New et al., 2012). In human tubular epithelial cells, Nox5 has been shown to be express together with Nox1, Nox4 and Nox2 but its role in HGinduced ROS production and cell injury was not studied (Yu et al., 2014b).

A potential upstream regulator of Nox4 expression in the tubules is protein kinase C- $\beta$ since diabetes-induced Nox4 expression and oxidative stress are attenuated in renal cortex from PKC- $\beta$-null mice kidney (Ohshiro et al., 2006). Interestingly, PKC seems to be positioned both upstream and downstream of Nox4 since it was recently reported that the increase in the major isoforms of PKC in tubules was blunted in the renal cortex from diabetic Nox4 knockout mice (Thallas-Bonke et al., 2014). A role for matrix metalloprotease a disintegrin and metalloprotease1 7 (ADAM17) as upstream regulator of Nox4 was recently established in vivo and in vitro. Pharmacological inhibition of ADAM17 attenuated diabetes-mediated Nox4 upregulation, oxidative stress and matrix protein accumulation in OVE26 mice kidney cortex (Ford et al., 2013). In cultured tubular epithelial cells, ADAM17 activity is required for HGinduced increase in Nox4 protein expression, ROS generation and fibrotic injury (Ford et al., 2013). Similar to podocytes, AMPK activation attenuates HG-mediated Nox4 protein upregulation in tubular epithelial cells, supporting the concept that the kinase acts as a suppressor of oxidative stress (Lee et al., 2013b). p38MAPK has been also identified as a critical downstream effector of Nox4 in the signaling pathway linking
HG and tubular cell injury (Sedeek et al., 2010).

Ang II has been shown to utilize Nox4 as a mediator of its injurious effects in tubular epithelial cells. Chronic angiotensin II treatment upregulates Nox4 expression and induces epithelialto-mesenchymal transition in renal epithelial cells through Nox4-dependent ROS production and resultant Src/caveolinmediated activation of epidermal growth factor receptor/ERK signaling pathway (Chen et al., 2012; Peng et al., 2009; Xu et al., 2010). Furthermore, Ang II upregulates Nox4 expression in the mitochondrial fraction of renal tubular cells and Nox4 is required for Ang II-mediated ROS mitochondrial production (Kim et al., 2012). ROS derived from Nox4 contribute to Ang IIdependent apoptosis in these cells (Kim et al., 2012). Ang II enhances the expression of Nox2, p22phox and p47phox subunits along with Nox4 in tubular cells (Hannken et al., 1998; Xu et al., 2010). The effects on p22phox, p47phox and Nox4 appear to be mediated by lectin-like oxidized low-density lipoprotein receptor-1 (Hannken et al., 1998; Xu et al., 2010). Another report shows that $\mathrm{HG}$ induces p22phox expression and oxidative stress via angiotensin II type $1\left(\mathrm{AT}_{1}\right)$ receptor activation, further underlining the important role of Ang $\mathrm{II}$ as a regulator of Nox signaling in tubular cells (Takao et al., 2011). Furthermore, a p22phox-containing NADPH oxidase is critical for Ang IImediated tubular cell hypertrophy through induction of p27Kip1, a factor promoting cell cycle arrest (Hannken et al., 1998). As in mesangial cells, Src and ERK pathways appears to be a primary target of Nox4-derived ROS and plays a key role in the resultant fibrotic or hypertrophic response in tubular cells. AMPK also inhibits Ang II-induced increase in Nox4 expression and tubular epithelial-to-mesenchymal transition (EMT) (Lee et al., 2013b).

Although it is clear that oxidative stress is implicated in TGF$\beta$-mediated tubular cell injury (Rhyu et al., 2005), there is a deficit of causal evidence supporting the role of the oxidase or other Nox enzymes in TGF- $\beta$ signaling in tubular cells. Stimulation of tubular cells by TGF- $\beta$ results in an increase in Nox4 protein expression, an effect prevented by AMPK activation (Lee et al., 2013b). Conflicting results exist concerning the regulation of other Nox subunits by TGF- $\beta$ in these cells. On one hand, TGF- $\beta$ has no effect on Nox2, p22phox and p47phox expression and that only p67phox seems to be required for the deleterious actions of the cytokine in renal tubular cells (Zhang et al., 2009). On the other hand, TGF- $\beta$ was shown to upregulate p22phox (Lee et al., 2003). Nox4-derived ROS also serve as signal transducer for the fibrotic effects of IGF-I in renal tubular epithelial cells via Akt/PKB and mTORC1/p70 S6K signaling pathways activation (New et al., 2012).

Figure 4 is an overview of the major redox pathways and signaling intermediates positioned upstream and downstream of Nox enzymes that are stimulated by diabetic stimuli to promote tubulointerstitial cell injury.

\section{UPSTREAM REGULATORS AND DOWNSTREAM EFFECTORS OF NOX NADPH OXIDASES IN DIABETES-INDUCED INTERSTITIAL CELL INJURY}

The information regarding the roles of hyperglycemia-mediated oxidative stress or Nox-derived ROS in interstitial cell injury, particularly in the activation of renal fibroblast into myofibroblasts, remains very limited. There is indication that exposure of kidney fibroblasts to $\mathrm{HG}$ upregulates Nox4 and Nox2 mRNA and protein expression and that this is associated with an increase in ROS generation and hypertrophy (Williams and Gooch, 2014). Calcineurin A- $\beta$ (CnA $\beta)$ maintains basal Nox4 


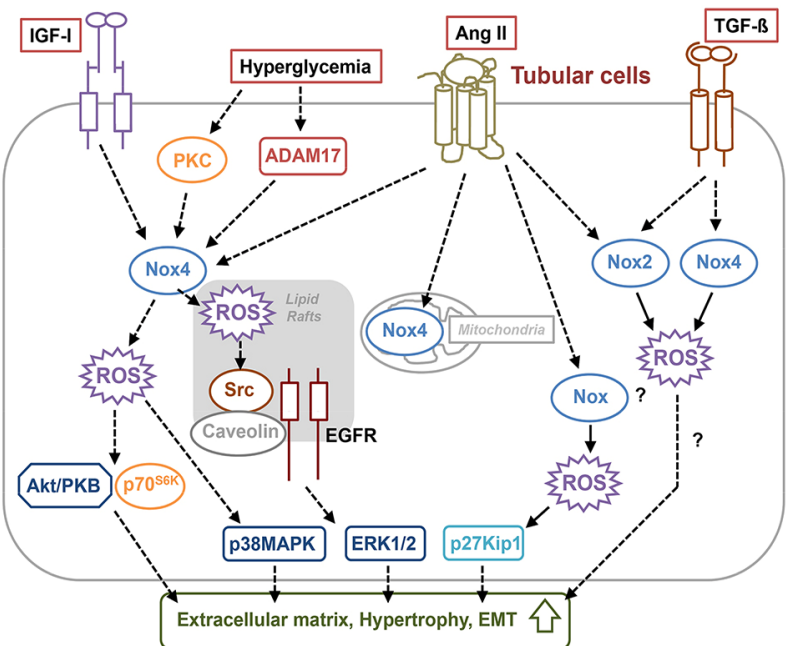

Fig. 4. Upstream and downstream effectors of Nox oxidases implicated in tubular cell injury triggered by diabetic stimuli. See text for detail.

and Nox2 expression and is required for HG-induced increase in Nox4 and Nox2 expression in these cells (Williams and Gooch, 2014). It seems that CnA $\beta$ promotes Nox4 and Nox2 transcription via activation of the nuclear factor of activated $T$ cells (NFAT) (Williams and Gooch, 2014). A functional link between Nox4 or Nox2 and ROS generation and hypertrophy is suggested by the fact that expression of Nox4 or Nox 2 in $\operatorname{CnA} \beta$ deficient kidney fibroblasts (where Nox4 and Nox2 are downregulated) is able to restore the stimulatory effects of $\mathrm{HG}$ on these biological outcomes (Williams and Gooch, 2014).

Nox4 is the predominant Nox homolog implicated in kidney myofibroblast differentiation and expression of fibronectin and other fibrotic markers in response to TGF- $\beta$ (Barnes and Gorin, 2011; Bondi et al., 2010). However, unlike cardiac and lung myofibroblasts where Nox4 acts upstream of transcription factor Smad2/3, Nox4 is positioned downstream of Smad3 and proximal to ERK in the pathway linking TGF- $\beta$ to the fibrotic response in renal fibroblasts (Barnes and Gorin, 2011; Cucoranu et al., 2005; Hecker et al., 2009). These results are in agreement with what is reported in pulmonary vascular smooth muscle cells, where TGF- $\beta$-induced proliferation occurs through a Nox4-dependent pathway downstream of Smad3 (Sturrock et al., 2006). Small GTPase RhoA and its downstream target Rho kinase (ROCK) have been identified as upstream positive regulators of Nox4 expression and activity in the pathway linking TGF- $\beta$ to kidney myofibroblast differentiation (Manickam et al., 2014). Interestingly, RhoA/ROCK seems to act via the increasing the expression of Poldip2, a newly discovered Nox4 enhancer protein (Manickam et al., 2014). Moreover, the data suggest that besides enhancing Nox4 activity Poldip2 is also able to regulate the expression of the oxidase.

\section{CONCLUSION}

It is apparent from this review that the in vivo and in vitro experimental evidence support a fundamental role for NADPH oxidases of the Nox family, and especially the homologue Nox4, in the pathogenesis and pathophysiology of DN. The consequence of these observations is the consideration of the Nox homologs and their associated subunits as relevant therapeutic targets for the treatment of DN. There has been recently a considerable effort for the generation and development of agents able to inhibit the Nox enzymes in a homolog-specific manner (Altenhofer et al., 2012; Drummond et al., 2011; Gaggini et al., 2011; Jaquet et al., 2009; Kim et al., 2011; Laleu et al., 2010; Lambeth et al., 2008). Among these inhibitors, the smallmolecule dual Nox4 and Nox1 inhibitors from the Pyrazolo pyridine chemical series, referred as to GKT136901 and GKT137831, have drawn considerable attention. Preclinical studies performed with these inhibitors in experimental animal models indicate that they effectively attenuate the pathological changes observed in renal complication of type 1 and type 2 diabetes, atherosclerosis, ischemic retinopathy, liver fibrosis and idiopathic pulmonary fibrosis (Aoyama et al., 2012; Carnesecchi et al., 2011; Di Marco et al., 2014; Gorin and Block, 2013a; 2013b; Gray et al., 2013; Hecker et al., 2014; Jha et al., 2014; Jiang et al., 2012; 2014; Laleu et al., 2010; Sedeek et al., 2013; Vendrov et al., 2010; Wilkinson-Berka et al., 2014). GKT137831 have recently been successfully used in a phase 1 clinical trial and is currently being evaluated in a phase 2 clinical trial in patients with type 2 diabetes and albuminuria (ClinicalTrials.gov reference number NCT02010242).

Beside the direct inhibition of Nox4 and others Nox oxidases, the present review suggests that adjunct therapies targeting the agonists or signaling intermediates that regulate the expression or function of Nox subunits and subsequent ROS production as well as the downstream targets of Nox oxidases implicated in the pathological processes should be considered for the treatment of diabetic complications. In regards to the observation reported above, such strategies could involve the use of PKC inhibitors, agents that disrupt the AGE signaling, inhibitors of the renin-angiotensin system (angiotensin-converting enzyme inhibitors and Ang II receptor blockers), statins (that inhibit Rac1 and Rho), Rho/Rho kinase inhibitors, AMPK activators (i.e. metformin), Sestrin-mimicking small molecules or peptides Sestrin analogues/agents that stimulate Sestrin activity or expression. Importantly, the small molecules Nox inhibitors that are currently available affect Nox activity without altering the expression of the oxidases. Therefore, the utilization of agents that modulate Nox expression or that target downstream effectors of the oxidases as adjunct therapy to Nox allosteric inhibitors may allow a more effective neutralization of the enzyme due to the blockade of the sustained increase in Nox protein levels promoted by chronic hyperglycemia or other mediators of DN.

\section{ACKNOWLEDGMENTS}

Supported by Juvenile Diabetes Research Foundation Multiproject Grants (Y.G), National Center for Advancing Translational Sciences, National Institutes of Health, through Grant UL1 TR001120 (Y.G.), and a NIH RO1 DK 079996 (Y.G.).

\section{REFERENCES}

Abboud, H.E. (1997). Growth factors and diabetic nephrology: an overview. Kidney Int. Supplement 60, S3-6.

Ago, T., Kuroda, J., Pain, J., Fu, C., Li, H., and Sadoshima, J. (2010). Upregulation of Nox4 by hypertrophic stimuli promotes apoptosis and mitochondrial dysfunction in cardiac myocytes. Circ. Res. 106, 1253-1264.

Altenhofer, S., Kleikers, P.W., Radermacher, K.A., Scheurer, P Rob Hermans, J.J., Schiffers, P., Ho, H., Wingler, K., and Schmidt, H.H. (2012). The NOX toolbox: validating the role of NADPH oxidases in physiology and disease. Cell. Mol. Life Sci. $69,2327-2343$. 
Aoyama, T., Paik, Y.H., Watanabe, S., Laleu, B., Gaggini, F. Fioraso-Cartier, L., Molango, S., Heitz, F., Merlot, C., Szyndralewiez, C., et al. (2012). Nicotinamide adenine dinucleotide phosphate oxidase in experimental liver fibrosis: GKT137831 as a novel potential therapeutic agent. Hepatology 56, 2316-2327.

Asaba, K., Tojo, A., Onozato, M.L., Goto, A., Quinn, M.T., Fujita, T., and Wilcox, C.S. (2005). Effects of NADPH oxidase inhibitor in diabetic nephropathy. Kidney Int. 67, 1890-1898.

Barnes, J.L., and Gorin, Y. (2011). Myofibroblast differentiation during fibrosis: role of $\mathrm{NAD}(\mathrm{P}) \mathrm{H}$ oxidases. Kidney Int. 79, 944956.

Baynes, J.W. (1991). Role of oxidative stress in development of complications in diabetes. Diabetes 40, 405-412.

Bedard, K., and Krause, K.H. (2007). The NOX family of ROSgenerating NADPH oxidases: physiology and pathophysiology Physiol. Rev. 87, 245-313.

Block, K., Eid, A., Griendling, K.K., Lee, D.Y., Wittrant, Y., and Gorin, Y. (2008). Nox4 NAD(P)H oxidase mediates Src-dependent tyrosine phosphorylation of PDK-1 in response to angiotensin II: role in mesangial cell hypertrophy and fibronectin expression. $\mathrm{J}$. Biol. Chem. 283, 24061-24076.

Block, K., Gorin, Y., and Abboud, H.E. (2009). Subcellular localization of Nox4 and regulation in diabetes. Proc. Natl. Acad. Sci. USA 106, 14385-14390.

Block, K., Ricono, J.M., Lee, D.Y., Bhandari, B., Choudhury, G.G., Abboud, H.E., and Gorin, Y. (2006). Arachidonic acid-dependent activation of a p22(phox)-based $\mathrm{NAD}(\mathrm{P}) \mathrm{H}$ oxidase mediates angiotensin II-induced mesangial cell protein synthesis and fibronectin expression via Akt/PKB. Antioxid. Redox Signal. 8, 1497-1508.

Bondi, C.D., Manickam, N., Lee, D.Y., Block, K., Gorin, Y., Abboud, H.E., and Barnes, J.L. (2010). NAD(P)H oxidase mediates TGFbeta1-induced activation of kidney myofibroblasts. J. Am. Soc. Nephrol. 21, 93-102.

Brandes, R.P., and Schroder, K. (2008). Composition and functions of vascular nicotinamide adenine dinucleotide phosphate oxidases. Trends Cardiovasc. Med. 18, 15-19.

Brandes, R.P., Weissmann, N., and Schroder, K. (2010). NADPH oxidases in cardiovascular disease. Free Radic. Bio. Med. 49, 687-706.

Brown, D.I., and Griendling, K.K. (2009). Nox proteins in signal transduction. Free Radic. Bio. Med. 47, 1239-1253.

Brownlee, M. (2005). The pathobiology of diabetic complications: a unifying mechanism. Diabetes 54, 1615-1625.

Campbell, K.N., Raij, L., and Mundel, P. (2011). Role of angiotensin II in the development of nephropathy and podocytopathy of diabetes. Curr. Diabetes Rev. 7, 3-7.

Carnesecchi, S., Deffert, C., Donati, Y., Basset, O., Hinz, B. Preynat-Seauve, O., Guichard, C., Arbiser, J.L., Banfi, B., Pache, J.C., et al. (2011). A key role for NOX4 in epithelial cell death during development of lung fibrosis. Antioxid. Redox Signal. 15, 607-619.

Chai, D., Wang, B., Shen, L., Pu, J., Zhang, X.K., and He, B. (2008). RXR agonists inhibit high-glucose-induced oxidative stress by repressing PKC activity in human endothelial cells. Free Radic. Bio. Med. 44, 1334-1347

Chen, J., Chen, J.K., and Harris, R.C. (2012). Angiotensin II induces epithelial-to-mesenchymal transition in renal epithelial cells through reactive oxygen species/Src/caveolin-mediated activation of an epidermal growth factor receptor-extracellular signal-regulated kinase signaling pathway. Mol. Cell. Biol. 32, 981-991.

Clempus, R.E., Sorescu, D., Dikalova, A.E., Pounkova, L., Jo, P. Sorescu, G.P., Schmidt, H.H., Lassegue, B., and Griendling, K.K. (2007). Nox4 is required for maintenance of the differentiated vascular smooth muscle cell phenotype. Arterioscler. Thromb. Vasc. Biol. 27, 42-48.

Coughlan, M.T., Thorburn, D.R., Penfold, S.A., Laskowski, A., Harcourt, B.E., Sourris, K.C., Tan, A.L., Fukami, K., ThallasBonke, V., Nawroth, P.P., et al. (2009). RAGE-induced cytosolic ROS promote mitochondrial superoxide generation in diabetes. J. Am. Soc. Nephrol. 20, 742-752.

Craven, P.A., Phillips, S.L., Melhem, M.F., Liachenko, J., and DeRubertis, F.R. (2001). Overexpression of manganese superoxide dismutase suppresses increases in collagen accumulation induced by culture of mesangial cells in high-media glucose.
Metabolism 50, 1043-1048

Cucoranu, I., Clempus, R., Dikalova, A., Phelan, P.J., Ariyan, S. Dikalov, S., and Sorescu, D. (2005). NAD(P)H oxidase 4 mediates transforming growth factor-beta1-induced differentiation of cardiac fibroblasts into myofibroblasts. Circ. Res. 97, 900-907.

Das, R., Xu, S., Quan, X., Nguyen, T.T., Kong, I.D., Chung, C.H., Lee, E.Y., Cha, S.K., and Park, K.S. (2014). Upregulation of mitochondrial Nox4 mediates TGF-beta-induced apoptosis in cultured mouse podocytes. Am. J. Physiol. Renal Physiol. 306, F155-167.

de Mochel, N.S., Seronello, S., Wang, S.H., Ito, C., Zheng, J.X., Liang, T.J., Lambeth, J.D., and Choi, J. (2010). Hepatocyte $\mathrm{NAD}(\mathrm{P}) \mathrm{H}$ oxidases as an endogenous source of reactive oxygen species during hepatitis $\mathrm{C}$ virus infection. Hepatology 52 , 47-59.

Di Marco, E., Gray, S.P., Chew, P., Koulis, C., Ziegler, A Szyndralewiez, C., Touyz, R.M., Schmidt, H.H., Cooper, M.E., Slattery, R., et al. (2014). Pharmacological inhibition of NOX reduces atherosclerotic lesions, vascular ROS and immuneinflammatory responses in diabetic Apoe(-/-) mice. Diabetologia 57, 633-642

Diaz, B., Shani, G., Pass, I., Anderson, D., Quintavalle, M., and Courtneidge, S.A. (2009). Tks5-dependent, nox-mediated generation of reactive oxygen species is necessary for invadopodia formation. Sci. Signal. 2, ra53.

Dikalov, S. (2011). Cross talk between mitochondria and NADPH oxidases. Free Radic. Biol. Med. 51, 1289-1301.

Ding, G., Zhang, A., Huang, S., Pan, X., Zhen, G., Chen, R., and Yang, T. (2007). ANG II induces c-Jun NH2-terminal kinase activation and proliferation of human mesangial cells via redoxsensitive transactivation of the EGFR. Am. J. Physiol. Renal. Physiol. 293, F1889-1897.

Drummond, G.R., Selemidis, S., Griendling, K.K., and Sobey, C.G. (2011). Combating oxidative stress in vascular disease: NADPH oxidases as therapeutic targets. Nat. Rev. 10, 453-471.

Eid, A.A., Gorin, Y., Fagg, B.M., Maalouf, R., Barnes, J.L., Block, K., and Abboud, H.E. (2009). Mechanisms of podocyte injury in diabetes: role of cytochrome P450 and NADPH oxidases. Diabetes 58, 1201-1211.

Eid, A.A., Ford, B.M., Block, K., Kasinath, B.S., Gorin, Y., GhoshChoudhury, G., Barnes, J.L., and Abboud, H.E. (2010). AMP activated protein kinase (AMPK) negatively regulates Nox4dependent activation of p53 and epithelial cell apoptosis in diabetes. J. Biol. Chem. 285, 37503-37512.

Eid, A.A., Ford, B.M., Bhandary, B., de Cassia Cavaglieri, R., Block, K., Barnes, J.L., Gorin, Y., Choudhury, G.G., and Abboud, H.E. (2013a). Mammalian target of rapamycin regulates Nox4mediated podocyte depletion in diabetic renal injury. Diabetes 62, 2935-2947.

Eid, A.A., Lee, D.Y., Roman, L.J., Khazim, K., and Gorin, Y. (2013b). Sestrin 2 and AMPK connect hyperglycemia to Nox4dependent endothelial nitric oxide synthase uncoupling and matrix protein expression. Mol. Cell. Biol. 33, 3439-3460.

Etoh, T., Inoguchi, T., Kakimoto, M., Sonoda, N., Kobayashi, K., Kuroda, J., Sumimoto, H., and Nawata, H. (2003). Increased expression of $\mathrm{NAD}(\mathrm{P}) \mathrm{H}$ oxidase subunits, NOX4 and p22phox, in the kidney of streptozotocin-induced diabetic rats and its reversibity by interventive insulin treatment. Diabetologia 46 , 1428-1437.

Forbes, J.M., Coughlan, M.T., and Cooper, M.E. (2008). Oxidative stress as a major culprit in kidney disease in diabetes. Diabetes 57, 1446-1454.

Ford, B.M., Eid, A.A., Gooz, M., Barnes, J.L., Gorin, Y.C., and Abboud, H.E. (2013). ADAM17 mediates Nox4 expression and NADPH oxidase activity in the kidney cortex of OVE26 mice. Am. J. Physiol. Renal. Physiol. 305, F323-332.

Fu, Y., Zhang, Y., Wang, Z., Wang, L., Wei, X., Zhang, B., Wen, Z Fang, H., Pang, Q., and Yi, F. (2010). Regulation of NADPH oxidase activity is associated with miRNA-25-mediated NOX4 expression in experimental diabetic nephropathy. Am. J. Nephrol. 32, 581-589.

Fujii, M., Inoguchi, T., Maeda, Y., Sasaki, S., Sawada, F., Saito, R., Kobayashi, K., Sumimoto, H., and Takayanagi, R. (2007). Pitavastatin ameliorates albuminuria and renal mesangial expansion by downregulating NOX4 in $\mathrm{db} / \mathrm{db}$ mice. Kidney Int. 72, 473-480. 
Fujii, M., Inoguchi, T., Sasaki, S., Maeda, Y., Zheng, J., Kobayashi K., and Takayanagi, R. (2010). Bilirubin and biliverdin protect rodents against diabetic nephropathy by downregulating $\mathrm{NAD}(\mathrm{P}) \mathrm{H}$ oxidase. Kidney Int. 78, 905-919.

Gaggini, F., Laleu, B., Orchard, M., Fioraso-Cartier, L., Cagnon, L., Houngninou-Molango, S., Gradia, A., Duboux, G., Merlot, C., Heitz, F., et al. (2011). Design, synthesis and biological activity of original pyrazolo-pyrido-diazepine, -pyrazine and -oxazine dione derivatives as novel dual Nox4/Nox1 inhibitors. Bioorg. Med. Chem. 19, 6989-6999.

Geiszt, M. (2006). NADPH oxidases: new kids on the block. Cardiov. Res. 71, 289-299.

Geiszt, M., Kopp, J.B., Varnai, P., and Leto, T.L. (2000). Identification of renox, an NAD(P)H oxidase in kidney. Proc. Natl. Acad. Sci. USA 97, 8010-8014.

Giacco, F., and Brownlee, M. (2010). Oxidative stress and diabetic complications. Circ. Res. 107, 1058-1070.

Gill, P.S. and Wilcox, C.S. (2006). NADPH oxidases in the kidney. Antioxid. Redox Signal. 8, 1597-1607.

Gojo, A., Utsunomiya, K., Taniguchi, K., Yokota, T., Ishizawa, S., Kanazawa, Y., Kurata, H., and Tajima, N. (2007). The Rhokinase inhibitor, fasudil, attenuates diabetic nephropathy in streptozotocin-induced diabetic rats. Eur. J. Pharmacol. 568, 242-247.

Gorin, Y., and Block, K. (2013a). Nox4 and diabetic nephropathy: With a friend like this, who needs enemies? Free Radic. Biol. Med. 61C, 130-142.

Gorin, Y., and Block, K. (2013b). Nox as a target for diabetic complications. Clin. Sci (Lond) 125, 361-382.

Gorin, Y., Block, K., Hernandez, J., Bhandari, B., Wagner, B., Barnes, J.L., and Abboud, H.E. (2005). Nox4 NAD(P)H oxidase mediates hypertrophy and fibronectin expression in the diabetic kidney. J. Biol. Chem. 280, 39616-39626.

Gorin, Y., Ricono, J.M., Kim, N.H., Bhandari, B., Choudhury, G.G. and Abboud, H.E. (2003). Nox4 mediates angiotensin II-induced activation of Akt/protein kinase B in mesangial cells. Am. J. Physiol. Renal Physiol. 285, F219-229.

Gorin, Y., Ricono, J.M., Wagner, B., Kim, N.H., Bhandari, B., Choudhury, G.G., and Abboud, H.E. (2004). Angiotensin IIinduced ERK1/ERK2 activation and protein synthesis are redoxdependent in glomerular mesangial cells. Biochem. J. 381, 231 239.

Gray, S.P., Di Marco, E., Okabe, J., Szyndralewiez, C., Heitz, F., Montezano, A.C., de Haan, J.B., Koulis, C., El-Osta, A., Andrews, K.L., et al. (2013). NADPH oxidase 1 plays a key role in diabetes mellitus-accelerated atherosclerosis. Circulation 127 1888-1902.

Greiber, S., Munzel, T., Kastner, S., Muller, B., Schollmeyer, P., and Pavenstadt, $H$. (1998). NAD(P)H oxidase activity in cultured human podocytes: effects of adenosine triphosphate. Kidney Int $53,654-663$.

Griendling, K.K., and FitzGerald, G.A. (2003). Oxidative stress and cardiovascular injury: Part I: basic mechanisms and in vivo monitoring of ROS. Circulation 108, 1912-1916.

Hannken, T., Schroeder, R., Stahl, R.A., and Wolf, G. (1998) Angiotensin II-mediated expression of p27Kip1 and induction of cellular hypertrophy in renal tubular cells depend on the generation of oxygen radicals. Kidney Int. 54, 1923-1933.

Hecker, L., Logsdon, N.J., Kurundkar, D., Kurundkar, A., Bernard, K., Hock, T., Meldrum, E., Sanders, Y.Y., and Thannickal, V.J. (2014). Reversal of persistent fibrosis in aging by targeting Nox4-Nrf2 redox imbalance. Sci. Trans. Med. 6, 231ra247.

Hecker, L., Vittal, R., Jones, T., Jagirdar, R., Luckhardt, T.R., Horowitz, J.C., Pennathur, S., Martinez, F.J., and Thannickal, V.J. (2009). NADPH oxidase-4 mediates myofibroblast activation and fibrogenic responses to lung injury. Nat. Med. 15 1077-1081.

Hinokio, Y., Suzuki, S., Hirai, M., Chiba, M., Hirai, A., and Toyota, T. (1999). Oxidative DNA damage in diabetes mellitus: its association with diabetic complications. Diabetologia 42, 995-998.

Holterman, C.E., Thibodeau, J.F., Towaij, C., Gutsol, A., Montezano, A.C., Parks, R.J., Cooper, M.E., Touyz, R.M., and Kennedy, C.R. (2014). Nephropathy and elevated BP in mice with podocytespecific NADPH oxidase 5 expression. J. Am. Soc. Nephrol. 25, 784-797.

Hua, H., Munk, S., Goldberg, H., Fantus, I.G., and Whiteside, C.I.
(2003). High glucose-suppressed endothelin-1 $\mathrm{Ca}^{2+}$ signaling via NADPH oxidase and diacylglycerol-sensitive protein kinase C isozymes in mesangial cells. J. Biol. Chem. 278, 33951-33962.

Hwang, I., Lee, J., Huh, J.Y., Park, J., Lee, H.B., Ho, Y.S., and Ha, $H$. (2012). Catalase deficiency accelerates diabetic renal injury through peroxisomal dysfunction. Diabetes 61, 728-738.

Ito, N., Ruegg, U.T., Kudo, A., Miyagoe-Suzuki, Y., and Takeda, S. (2013). Activation of calcium signaling through Trpv1 by nNOS and peroxynitrite as a key trigger of skeletal muscle hypertrophy. Nat. Med. 19, 101-106.

Jaquet, V., Scapozza, L., Clark, R.A., Krause, K.H., and Lambeth, J.D. (2009). Small-molecule NOX inhibitors: ROS-generating NADPH oxidases as therapeutic targets. Antioxid. Redox Signal. 11, 2535-2552.

Jeong, S.I., Kim, S.J., Kwon, T.H., Yu, K.Y., and Kim, S.Y. (2012). Schizandrin prevents damage of murine mesangial cells via blocking NADPH oxidase-induced ROS signaling in high glucose. Food Chem. Toxicol. 50, 1045-1053.

Jha, J.C., Gray, S.P., Barit, D., Okabe, J., El-Osta, A., Namikoshi, T., Thallas-Bonke, V., Wingler, K., Szyndralewiez, C., Heitz, F. et al. (2014). Genetic targeting or pharmacologic inhibition of NADPH oxidase nox4 provides renoprotection in long-term diabetic nephropathy. J. Am. Soc. Nephrol. 25, 1237-1254.

Jiang, J.X., Chen, X., Serizawa, N., Szyndralewiez, C., Page, P. Schroder, K., Brandes, R.P., Devaraj, S., and Torok, N.J. (2012). Liver fibrosis and hepatocyte apoptosis are attenuated by GKT137831, a novel NOX4/NOX1 inhibitor in vivo. Free Radic. Biol. Med. 53, 289-296.

Jones, S.A., Hancock, J.T., Jones, O.T., Neubauer, A., and Topley, N. (1995). The expression of NADPH oxidase components in human glomerular mesangial cells: detection of protein and mRNA for p47phox, p67phox, and p22phox. J. Am. Soc. Nephrol. 5, 1483-1491.

Kanwar, Y.S., Sun, L., Xie, P., Liu, F.Y., and Chen, S. (2011). A glimpse of various pathogenetic mechanisms of diabetic nephropathy. Ann. Rev. Pathol. 6, 395-423.

Kanwar, Y.S., Wada, J., Sun, L., Xie, P., Wallner, E.I., Chen, S. Chugh, S., and Danesh, F.R. (2008). Diabetic nephropathy: mechanisms of renal disease progression. Exp. Biol. Med. 233 4-11.

Kashihara, N., Haruna, Y., Kondeti, V.K., and Kanwar, Y.S. (2010). Oxidative stress in diabetic nephropathy. Curr. Med. Chem. 17 4256-4269.

Khazim, K., Gorin, Y., Cavaglieri, R.C., Abboud, H.E., and Fanti, P. (2013). The antioxidant silybin prevents high glucose-induced oxidative stress and podocyte injury in vitro and in vivo. Am. J. Physiol. Renal Physiol. 305, F691-700.

Kim, J.A., Neupane, G.P., Lee, E.S., Jeong, B.S., Park, B.C., and Thapa, P. (2011). NADPH oxidase inhibitors: a patent review. Expert Opin. Ther. Pat. 21, 1147-1158.

Kim, S.M., Kim, Y.G., Jeong, K.H., Lee, S.H., Lee, T.W., Ihm, C.G and Moon, J.Y. (2012). Angiotensin Il-induced mitochondria Nox4 is a major endogenous source of oxidative stress in kidney tubular cells. PLoS One 7, e39739.

Kiritoshi, S., Nishikawa, T., Sonoda, K., Kukidome, D., Senokuchi, T., Matsuo, T., Matsumura, T., Tokunaga, H., Brownlee, M., and Araki, E. (2003). Reactive oxygen species from mitochondria induce cyclooxygenase-2 gene expression in human mesangial cells: potential role in diabetic nephropathy. Diabetes 52,2570 2577.

Kitada, M., Koya, D., Sugimoto, T., Isono, M., Araki, S., Kashiwagi, A., and Haneda, M. (2003). Translocation of glomerular p47phox and p67phox by protein kinase $\mathrm{C}$-beta activation is required for oxidative stress in diabetic nephropathy. Diabetes 52, 26032614.

Kitada, M., Kume, S., Imaizumi, N., and Koya, D. (2011). Resveratrol improves oxidative stress and protects against diabetic nephropathy through normalization of Mn-SOD dysfunction in AMPK/SIRT1-independent pathway. Diabetes 60, 634-643.

Koya, D., Hayashi, K. Kitada, M. Kashiwagi, A., Kikkawa, R., and Haneda, M. (2003). Effects of antioxidants in diabetes-induced oxidative stress in the glomeruli of diabetic rats. J. Am. Soc Nephrol. 14, S250-253.

Koziel, R., Pircher, H., Kratochwil, M., Lener, B., Hermann, M., Dencher, N.A., and Jansen-Durr, P. (2013). Mitochondrial respiratory chain complex I is inactivated by NADPH oxidase 
Nox4. Biochem. J. 452, 231-239.

Kuroda, J., Nakagawa, K., Yamasaki, T., Nakamura, K., Takeya, R., Kuribayashi, F., Imajoh-Ohmi, S., Igarashi, K., Shibata, Y., Sueishi, K., et al. (2005). The superoxide-producing $N A D(P) H$ oxidase Nox4 in the nucleus of human vascular endothelial cells. Genes Cells 10, 1139-1151.

Kuroda, J., Ago, T., Matsushima, S., Zhai, P., Schneider, M.D., and Sadoshima, J. (2010). NADPH oxidase 4 (Nox4). is a major source of oxidative stress in the failing heart. Proc. Natl. Acad. Sci. USA 107, 15565-15570.

Kwan, J., Wang, H., Munk, S., Xia, L., Goldberg, H.J., and Whiteside, C.I. (2005). In high glucose protein kinase C-zeta activation is required for mesangial cell generation of reactive oxygen species. Kidney Int. 68, 2526-2541.

Laleu, B., Gaggini, F., Orchard, M., Fioraso-Cartier, L., Cagnon, L., Houngninou-Molango, S., Gradia, A., Duboux, G., Merlot, C., Heitz, F., et al. (2010). First in class, potent, and orally bioavailable NADPH oxidase isoform 4 (Nox4). inhibitors for the treatment of idiopathic pulmonary fibrosis. J. Med. Chem. 53, 7715-7730.

Lambeth, J.D. (2007). Nox enzymes, ROS, and chronic disease: an example of antagonistic pleiotropy. Free Radic. Biol. Med. 43, 332-347.

Lambeth, J.D., Kawahara, T., and Diebold, B. (2007). Regulation of Nox and Duox enzymatic activity and expression. Free Radic. Biol. Med. 43, 319-331.

Lambeth, J.D., Krause, K.H., and Clark, R.A. (2008). NOX enzymes as novel targets for drug development. Semin. Immunopathol. 30, 339-363.

Lassegue, B., and Clempus, R.E. (2003). Vascular NAD(P).H oxidases: specific features, expression, and regulation. Am. J. Physiol. Regul. Integr. Comp. Physiol. 285, R277-297.

Lassegue, B., and Griendling, K.K. (2010). NADPH oxidases: functions and pathologies in the vasculature. Arterioscler. Thromb. Vasc. Biol. 30, 653-661.

Lassegue, B., Sorescu, D., Szocs, K., Yin, Q., Akers, M., Zhang, Y. Grant, S.L., Lambeth, J.D., and Griendling, K.K. (2001). Nove gp91(phox). homologues in vascular smooth muscle cells : nox1 mediates angiotensin II-induced superoxide formation and redox-sensitive signaling pathways. Circ. Res. 88, 888-894.

Lassegue, B., San Martin, A. and Griendling, K.K. (2012). Biochemistry, physiology, and pathophysiology of NADPH oxidases in the cardiovascular system. Circ. Res. 110, 1364-1390.

Lavrentyev, E.N., and Malik, K.U. (2009). High glucose-induced Nox1-derived superoxides downregulate PKC-betall, which subsequently decreases ACE2 expression and ANG(1-7) formation in rat VSMCs. Am. J. Physiol. Heart Circ. Physiol. 296, H106-118.

Lee, H.B., Yu, M.R., Yang, Y., Jiang, Z. and Ha, H. (2003). Reactive oxygen species-regulated signaling pathways in diabetic nephropathy. J. Am. Soc. Nephrol. 14, S241-245.

Lee, D.Y. Wauquier, F., Fid, A.A., Roman, L.J., Ghosh-Choudhury, G., Khazim, K., Block, K., and Gorin, Y. (2013a). Nox4 NADPH oxidase mediates peroxynitrite-dependent uncoupling of endothelial nitric-oxide synthase and fibronectin expression in response to angiotensin II: role of mitochondrial reactive oxygen species. J. Biol. Chem. 288, 28668-28686.

Lee, J.H., Kim, J.H., Kim, J.S., Chang, J.W., Kim, S.B., Park, J.S. and Lee, S.K. (2013b). AMP-activated protein kinase inhibits TGF-beta-, angiotensin II-, aldosterone-, high glucose-, and albumin-induced epithelial-mesenchymal transition. Am. J. Physiol. Renal Physiol. 304, F686-697.

Liu, G.C., Fang, F., Zhou, J., Koulajian, K., Yang, S., Lam, L., Reich, H.N., John, R., Herzenberg, A.M., Giacca, A., et al. (2012). Deletion of p47phox attenuates the progression of diabetic nephropathy and reduces the severity of diabetes in the Akita mouse. Diabetologia 55, 2522-2532.

Liu, R.M., Choi, J., Wu, J.H., Gaston Pravia, K.A., Lewis, K.M. Brand, J.D., Mochel, N.S., Krzywanski, D.M., Lambeth, J.D., Hagood, J.S., et al. (2010). Oxidative modification of nuclear mitogen-activated protein kinase phosphatase 1 is involved in transforming growth factor beta1-induced expression of plasminogen activator inhibitor 1 in fibroblasts. J. Biol. Chem. 285, 16239-16247.

Lyle, A.N., Deshpande, N.N., Taniyama, Y., Seidel-Rogol, B., Pounkova, L., Du, P., Papaharalambus, C., Lassegue, B. and Griendling, K.K. (2009). Poldip2, a novel regulator of Nox4 and cytoskeletal integrity in vascular smooth muscle cells. Circ. Res. 105, 249-259.

Maalouf, R.M., Eid, A.A., Gorin, Y.C., Block, K., Escobar, G.P., Bailey, S., and Abboud, H.E. (2012). Nox4-derived reactive oxygen species mediate cardiomyocyte injury in early type 1 diabetes. Am. J. Physiol. Cell Physiol. 302, C597-604.

Maeda, Y., Inoguchi, T., Takei, R., Sawada, F., Sasaki, S., Fujii, M., Kobayashi, K., Urata, H., Nishiyama, A., and Takayanagi, R. (2010). Inhibition of chymase protects against diabetes-induced oxidative stress and renal dysfunction in hamsters. Am. J. Physiol. Renal Physiol. 299, F1328-1338.

Mahadev, K., Motoshima, H., Wu, X., Ruddy, J.M., Arnold, R.S. Cheng, G., Lambeth, J.D., and Goldstein, B.J. (2004). The NAD(P).H oxidase homolog Nox4 modulates insulin-stimulated generation of $\mathrm{H} 2 \mathrm{O} 2$ and plays an integral role in insulin signal transduction. Mol. Cell. Biol. 24, 1844-1854.

Manickam, N., Patel, M., Griendling, K.K., Gorin, Y., and Barnes, J.L. (2014). RhoA/Rho kinase mediates TGF-beta1-induced kidney myofibroblast activation through Poldip2/Nox4-derived reactive oxygen species. Am. J. Physiol. Renal Physiol. 307, F159-171.

McCarty, M.F., Barroso-Aranda, J., and Contreras, F. (2009). AMPactivated kinase may suppress NADPH oxidase activation in vascular tissues. Med. Hypotheses 72, 468-470.

Meng, D., Lv, D.D., and Fang, J. (2008). Insulin-like growth factor-I induces reactive oxygen species production and cell migration through Nox4 and Rac1 in vascular smooth muscle cells. Cardiov. Res. 80, 299-308.

Menini, S., lacobini, C., Ricci, C., Oddi, G., Pesce, C., Pugliese, F., Block, K., Abboud, H.E., Giorgio, M., Migliaccio, E., et al. (2007). Ablation of the gene encoding p66Shc protects mice against AGE-induced glomerulopathy by preventing oxidant-dependent tissue injury and further AGE accumulation. Diabetologia 50, 1997-2007.

Mittal, M., Roth, M., Konig, P., Hofmann, S., Dony, E., Goyal, P Selbitz, A.C., Schermuly, R.T., Ghofrani, H.A., Kwapiszewska, G., et al. (2007). Hypoxia-dependent regulation of nonphagocytic NADPH oxidase subunit NOX4 in the pulmonary vasculature. Circ. Res. 101, 258-267.

Miyata, K., Rahman, M., Shokoji, T., Nagai, Y., Zhang, G.X., Sun, G.P., Kimura, S., Yukimura, T., Kiyomoto, H., Kohno, M., et al. (2005). Aldosterone stimulates reactive oxygen species production through activation of NADPH oxidase in rat mesangial cells. J. Am. Soc. Nephrol. 16, 2906-2912.

Moe, K.T., Aulia, S., Jiang, F., Chua, Y.L., Koh, T.H., Wong, M.C and Dusting, G.J. (2006). Differential upregulation of Nox homologues of NADPH oxidase by tumor necrosis factor-alpha in human aortic smooth muscle and embryonic kidney cells. J. Cell. Mol. Med. 10, 231-239.

New, D.D., Block, K., Bhandhari, B., Gorin, Y., and Abboud, H.E. (2012). IGF-I increases the expression of fibronectin by Nox4dependent Akt phosphorylation in renal tubular epithelial cells. Am. J. Physiol. Renal Physiol. 302, C122-130.

Nishikawa, T., Edelstein, D., Du, X.L., Yamagishi, S., Matsumura T., Kaneda, Y., Yorek, M.A., Beebe, D., Oates, P.J., Hammes, H.P., et al. (2000). Normalizing mitochondrial superoxide production blocks three pathways of hyperglycaemic damage. Nature 404, 787-790.

Nistala, R., Whaley-Connell, A., and Sowers, J.R. (2008). Redox control of renal function and hypertension. Antioxid. Redox Signal. 10, 2047-2089.

Octavia, Y., Brunner-La Rocca, H.P., and Moens, A.L. (2012). NADPH oxidase-dependent oxidative stress in the failing heart: From pathogenic roles to therapeutic approach. Free Radic. Biol. Med. 52, 291-297.

Ohshiro, Y., Ma, R.C., Yasuda, Y., Hiraoka-Yamamoto, J. Clermont, A.C., Isshiki, K., Yagi, K., Arikawa, E., Kern, T.S., and King, G.L. (2006). Reduction of diabetes-induced oxidative stress, fibrotic cytokine expression, and renal dysfunction in protein kinase Cbeta-null mice. Diabetes 55, 3112-3120.

Papadimitriou, A., Peixoto, E.B., Silva, K.C., Lopes de Faria, J.M., and Lopes de Faria, J.B. (2014). Increase in AMPK brought about by cocoa is renoprotective in experimental diabetes mellitus by reducing NOX4/TGFbeta-1 signaling. J. Nutr. Biochem. 25, 773-784.

Paravicini, T.M., and Touyz, R.M. (2008). NADPH oxidases, 
reactive oxygen species, and hypertension: clinical implications and therapeutic possibilities. Diabetes Care 31 Suppl 2, S170180.

Pedruzzi, E., Guichard, C., Ollivier, V., Driss, F., Fay, M., Prunet, C., Marie, J.C., Pouzet, C., Samadi, M., Elbim, C., et al. (2004). NAD(P).H oxidase Nox-4 mediates 7-ketocholesterol-induced endoplasmic reticulum stress and apoptosis in human aortic smooth muscle cells. Mol. Cell. Biol. 24, 10703-10717.

Peng, Z.Z., Hu, G.Y., Shen, H., Wang, L., Ning, W.B., Xie, Y.Y., Wang, N.S., Li, B.X., Tang, Y.T., and Tao, L.J. (2009). Fluorofenidone attenuates collagen I and transforming growth factor-beta1 expression through a nicotinamide adenine dinucleotide phosphate oxidase-dependent way in NRK-52E cells. Nephrology 14, 565-572.

Peshavariya, H., Jiang, F., Taylor, C.J., Selemidis, S., Chang, C.W., and Dusting, G.J. (2009). Translation-linked mRNA destabilization accompanying serum-induced Nox4 expression in human endothelial cells. Antioxid. Redox Signal. 11, 2399-2408.

Peshavariya, H.M., Dusting, G.J. and Selemidis, S. (2007). Analysis of dihydroethidium fluorescence for the detection of intracellula and extracellular superoxide produced by NADPH oxidase. Free Radic. Res. 41, 699-712.

Piwkowska, A., Rogacka, D., Audzeyenka, I., Jankowski, M., and Angielski, S. (2011). High glucose concentration affects the oxidant-antioxidant balance in cultured mouse podocytes. J. Cell. Biochem. 112, 1661-1672.

Piwkowska, A., Rogacka, D., Jankowski, M., Dominiczak, M.H., Stepinski, J.K. and Angielski, S. (2010). Metformin induces suppression of $\mathrm{NAD}(\mathrm{P}) . \mathrm{H}$ oxidase activity in podocytes. Biochem. Biophys. Res. Commun. 393, 268-273.

Pleskova, M., Beck, K.F., Behrens, M.H., Huwiler, A., Fichtlscherer, B., Wingerter, O., Brandes, R.P., Mulsch, A. and Pfeilschifter, J. (2006). Nitric oxide down-regulates the expression of the catalytic NADPH oxidase subunit Nox1 in rat renal mesangial cells. FASEB J. 20, 139-141.

Rhyu, D.Y., Yang, Y., Ha, H., Lee, G.T., Song, J.S., Uh, S.T. and Lee, H.B. (2005). Role of reactive oxygen species in TGF-beta1induced mitogen-activated protein kinase activation and epithelial-mesenchymal transition in renal tubular epithelial cells. J. Am. Soc. Nephrol. 16, 667-675.

Rincon-Choles, H., Kasinath, B.S., Gorin, Y. and Abboud, H.E. (2002). Angiotensin II and growth factors in the pathogenesis of diabetic nephropathy. Kidney Int. Supplement S8-11.

Rivera, J., Sobey, C.G., Walduck, A.K. and Drummond, G.R (2010). Nox isoforms in vascular pathophysiology: insights from transgenic and knockout mouse models. Redox Rep. 15, 50-63.

Schnackenberg, C.G. (2002). Oxygen radicals in cardiovascularrenal disease. Curr. Opin. Pharmacol. 2, 121-125.

Schuhmacher, S., Foretz, M., Knorr, M., Jansen, T., Hortmann, M., Wenzel, P., Oelze, M., Kleschyov, A.L., Daiber, A., Keaney, J.F., Jr., et al. (2011). alpha1AMP-activated protein kinase preserves endothelial function during chronic angiotensin II treatment by limiting Nox2 upregulation. Arterioscler. Thromb. Vasc. Biol. 31 , 560-566.

Sedeek, M., Callera, G., Montezano, A., Gutsol, A., Heitz, F., Szyndralewiez, C., Page, P., Kennedy, C.R., Burns, K.D., Touyz, R.M., et al. (2010). Critical role of Nox4-based NADPH oxidase in glucose-induced oxidative stress in the kidney: implications in type 2 diabetic nephropathy. Am. J. Physiol. Renal Physiol. 299, F1348-1358.

Sedeek, M., Gutsol, A., Montezano, A.C., Burger, D., Nguyen Dinh Cat, A., Kennedy, C.R., Burns, K.D., Cooper, M.E., JandeleitDahm, K., Page, P., et al. (2013). Renoprotective effects of a novel Nox $1 / 4$ inhibitor in a mouse model of Type 2 diabetes. Clin. Sci. 124, 191-202

Sedeek, M., Hebert, R.L., Kennedy, C.R., Burns, K.D. and Touyz, R.M. (2009). Molecular mechanisms of hypertension: role of Nox family NADPH oxidases. Curr. Opin. Nephrol. Hypertens. $18,122-127$

Sedeek, M., Montezano, A.C., Hebert, R.L., Gray, S.P., Di Marco, E., Jha, J.C., Cooper, M.E., Jandeleit-Dahm, K., Schiffrin, E.L., Wilkinson-Berka, J.L., et al. (2012). Oxidative stress, Nox isoforms and complications of diabetes--potential targets for novel therapies. J. Cardiovasc. Transl. Res. 5, 509-518.

Selemidis, S., Sobey, C.G., Wingler, K., Schmidt, H.H., and Drummond, G.R. (2008). NADPH oxidases in the vasculature: molecular features, roles in disease and pharmacological inhibition. Pharmacol. Ther. 120, 254-291.

Serrander, L., Cartier, L., Bedard, K., Banfi, B., Lardy, B., Plastre, O., Sienkiewicz, A., Forro, L., Schlegel, W., and Krause, K.H. (2007). NOX4 activity is determined by mRNA levels and reveals a unique pattern of ROS generation. Biochem. J. 406, 105-114.

Shah, A., Xia, L., Goldberg, H., Lee, K.W., Quaggin, S.E., and Fantus, I.G. (2013). Thioredoxin-interacting protein mediates high glucose-induced reactive oxygen species generation by mitochondria and the NADPH oxidase, Nox4, in mesangial cells. J. Biol. Chem. 288, 6835-6848.

Sharma, K., Ramachandrarao, S., Qiu, G., Usui, H.K., Zhu, Y Dunn, S.R., Ouedraogo, R., Hough, K., McCue, P., Chan, L., et al. (2008). Adiponectin regulates albuminuria and podocyte function in mice $\mathrm{J}$. Clin Invest 118, 1645-1656.

Shiose, A., Kuroda, J., Tsuruya, K., Hirai, M., Hirakata, H., Naito, S., Hattori, M., Sakaki, Y., and Sumimoto, H. (2001). A novel superoxide-producing $\mathrm{NAD}(\mathrm{P}) . \mathrm{H}$ oxidase in kidney. J. Biolo. Chem. 276, 1417-1423.

Singh, D.K., Winocour, P., and Farrington, K. (2011). Oxidative stress in early diabetic nephropathy: fueling the fire. Nat. Rev. 7 , 176-184.

Siu, K.L., Lotz, C., Ping, P., and Cai, H. (2015). Netrin-1 abrogates ischemia/reperfusion-induced cardiac mitochondrial dysfunction via nitric oxide-dependent attenuation of NOX4 activation and recoupling of NOS. J. Mol. Cell Cardiol. 78, 174-185.

Son, S.M., Whalin, M.K., Harrison, D.G., Taylor, W.R., and Griendling, K.K. (2004). Oxidative stress and diabetic vascular complications. Curr. Diabetes Rep. 4, 247-252.

Sonta, T., Inoguchi, T., Matsumoto, S., Yasukawa, K., Inuo, M., Tsubouchi, H., Sonoda, N., Kobayashi, K., Utsumi, H., and Nawata, $\mathrm{H}$. (2005). In vivo imaging of oxidative stress in the kidney of diabetic mice and its normalization by angiotensin II type 1 receptor blocker. Biochem. Biophys. Res. Commun. 330, 415-422.

Stanton, R.C. (2011). Oxidative stress and diabetic kidney disease. Curr. Diabetes Rep. 11, 330-336.

Sturrock, A., Cahill, B., Norman, K., Huecksteadt, T.P., Hill, K., Sanders, K., Karwande, S.V., Stringham, J.C., Bull, D.A., Gleich, M., et al. (2006). Transforming growth factor-beta1 induces Nox4 NAD(P).H oxidase and reactive oxygen speciesdependent proliferation in human pulmonary artery smooth muscle cells. Am. J. Physiol. Lung Cell. Mol. Physiol. 290, L661L673.

Takac, I., Schroder, K., Zhang, L., Lardy, B., Anilkumar, N., Lambeth, J.D., Shah, A.M., Morel, F. and Brandes, R.P. (2011) The E-loop is involved in hydrogen peroxide formation by the NADPH oxidase Nox4. J. Biol. Chem. 286, 13304-13313.

Takao, T., Horino, T., Kagawa, T., Matsumoto, R., Shimamura, Y., Ogata, K., Inoue, K., Taniguchi, Y., Taguchi, T., Morita, T., et al. (2011). Possible involvement of intracellular angiotensin II receptor in high-glucose-induced damage in renal proximal tubular cells. J. Nephrol. 24, 218-224.

Thallas-Bonke, V., Thorpe, S.R., Coughlan, M.T., Fukami, K., Yap, F.Y., Sourris, K.C., Penfold, S.A., Bach, L.A., Cooper, M.E. and Forbes, J.M. (2008). Inhibition of NADPH oxidase prevents advanced glycation end product-mediated damage in diabetic nephropathy through a protein kinase $\mathrm{C}$-alpha-dependent pathway. Diabetes 57, 460-469.

Thallas-Bonke, V., Jha, J.C., Gray, S.P., Barit, D., Haller, H. Schmidt, H.H., Coughlan, M.T., Cooper, M.E., Forbes, J.M. and Jandeleit-Dahm, K.A. (2014). Nox-4 deletion reduces oxidative stress and injury by PKC-alpha-associated mechanisms in diabetic nephropathy. Physiol. Rep. 2 pii: e1219.

Ushio-Fukai, M. (2006). Localizing NADPH oxidase-derived ROS. Sci. STKE 2006, re8.

Varga, Z.V., Kupai, K., Szucs, G., Gaspar, R., Paloczi, J., Farago, N., Zvara, A., Puskas, L.G., Razga, Z., Tiszlavicz, L., et al. (2013). MicroRNA-25-dependent up-regulation of NADPH oxidase 4 (NOX4) mediates hypercholesterolemia-induced oxidative/nitrative stress and subsequent dysfunction in the heart. J. Mol. Cell. Cardiol. 62, 111-121.

Vasavada, N., and Agarwal, R. (2005). Role of oxidative stress in diabetic nephropathy. Adv. Chronic. Kidney Dis. 12, 146-154.

Vendrov, A.E., Madamanchi, N.R., Niu, X.L., Molnar, K.C., Runge, 
M., Szyndralewiez, C., Page, P., and Runge, M.S. (2010). $\mathrm{NADPH}$ oxidases regulate $\mathrm{CD} 44$ and hyaluronic acid expression in thrombin-treated vascular smooth muscle cells and in atherosclerosis. J. Biol. Chem. 285, 26545-26557.

Wang, S., Zhang, M., Liang, B., Xu, J., Xie, Z., Liu, C., Viollet, B., Yan, D., and Zou, M.H. (2010). AMPKalpha2 deletion causes aberrant expression and activation of $\mathrm{NAD}(\mathrm{P}) \mathrm{H}$ oxidase and consequent endothelial dysfunction in vivo: role of $26 \mathrm{~S}$ proteasomes. Circ. Res. 106, 1117-1128.

Wei, X.F., Zhou, Q.G., Hou, F.F., Liu, B.Y., and Liang, M. (2009). Advanced oxidation protein products induce mesangial cell perturbation through PKC-dependent activation of NADPH oxidase. Am. J. Physiol. Renal Physiol. 296, F427-437.

Whaley-Connell, A., Habibi, J., Nistala, R., Cooper, S.A., Karuparthi, P.R., Hayden, M.R., Rehmer, N., DeMarco, V.G., Andresen, B.T., Wei, Y., et al. (2008). Attenuation of NADPH oxidase activation and glomerular filtration barrier remodeling with statin treatment. Hypertension 51, 474-480.

Whiteside, C., Wang, H., Xia, L., Munk, S., Goldberg, H.J., and Fantus, I.G. (2009). Rosiglitazone prevents high glucoseinduced vascular endothelial growth factor and collagen IV expression in cultured mesangial cells. Exp. Diabetes Res. 2009, 910783.

Wilkinson-Berka, J.L., Deliyanti, D., Rana, I., Miller, A.G., Agrotis, A., Armani, R., Szyndralewiez, C., Wingler, K., Touyz, R.M., Cooper, M.E., et al. (2014). NADPH oxidase, NOX1, mediates vascular injury in ischemic retinopathy. Antioxid. Redox Signal. 20, 27262740 .

Williams, C.R. and Gooch, J.L. (2014). Calcineurin Abeta regulates NADPH oxidase (Nox). expression and activity via nuclear factor of activated T cells (NFAT) in response to high glucose. J. Biol. Chem. 289, 4896-4905.

Wingler, K., Wunsch, S., Kreutz, R., Rothermund, L., Paul, M., and Schmidt, H.H. (2001). Upregulation of the vascular NAD(P)Hoxidase isoforms Nox1 and Nox4 by the renin-angiotensin system in vitro and in vivo. Free Radic. Biol. Med. 31, 14561464.

Wu, R.F., Ma, Z., Myers, D.P., and Terada, L.S. (2007). HIV-1 Tat activates dual Nox pathways leading to independent activation of ERK and JNK MAP kinases. J. Biol. Chem. 282, 3741237419 .

Xia, L., Wang, H., Goldberg, H.J., Munk, S., Fantus, I.G., and
Whiteside, C.I. (2006). Mesangial cell NADPH oxidase upregulation in high glucose is protein kinase $C$ dependent and required for collagen IV expression. Am. J. Physiol. Renal Physiol. 290, F345-356.

Xia, L., Wang, H., Munk, S., Kwan, J., Goldberg, H.J., Fantus, I.G., and Whiteside, C.I. (2008). High glucose activates PKC-zeta and NADPH oxidase through autocrine TGF-beta1 signaling in mesangial cells. Am. J. Physiol. Renal Physiol. 295, F17051714.

Xu, Y., Ruan, S., Xie, H., and Lin, J. (2010). Role of LOX-1 in Ang II-induced oxidative functional damage in renal tubular epithelial cells. Int. J. Mol. Med. 26, 679-690.

Yamagishi, S., Nakamura, K., Ueda, S., Kato, S., and Imaizumi, T. (2005). Pigment epithelium-derived factor (PEDF) blocks angiotensin II signaling in endothelial cells via suppression of NADPH oxidase: a novel anti-oxidative mechanism of PEDF. Cell Tissue Res. 320, 437-445

You, Y.H., Okada, S., Ly, S., Jandeleit-Dahm, K., Barit, D., Namikoshi, T. and Sharma, K. (2013). Role of Nox2 in diabetic kidney disease. Am. J. Physiol. Renal Physiol. 304, F840-848.

Yu, L., Liu, Y., Wu, Y., Liu, Q., Feng, J., Gu, X., Xiong, Y., Fan, Q. and Ye, J. (2014a). Smad3/Nox4-mediated mitochondrial dysfunction plays a crucial role in puromycin aminonucleosideinduced podocyte damage. Cell. Signal. 26, 2979-2991.

Yu, P., Han, W., Villar, V.A., Yang, Y., Lu, Q., Lee, H., Li, F., Quinn, M.T., Gildea, J.J., Felder, R.A., et al. (2014b). Unique role of NADPH oxidase 5 in oxidative stress in human renal proximal tubule cells. Redox Biol. 2, 570-579.

Zhang, H., Jiang, Z., Chang, J., Li, X., Zhu, H., Lan, H.Y., Zhou, S.F., and Yu, X. (2009). Role of NAD(P).H oxidase in transforming growth factor-beta1-induced monocyte chemoattractant protein-1 and interleukin- 6 expression in rat renal tubular epithelial cells. Nephrology 14, 302-310.

Zhang, L., Pang, S., Deng, B., Qian, L., Chen, J., Zou, J., Zheng, J., Yang, L., Zhang, C., Chen, X., et al. (2012). High glucose induces renal mesangial cell proliferation and fibronectin expression through JNK/NF-kappaB/NADPH oxidase/ROS pathway, which is inhibited by resveratrol. Int. J. Biochem. Cell Biol. 44, 629-638.

Ziyadeh, F.N., and Wolf, G. (2008) Pathogenesis of the podocytopathy and proteinuria in diabetic glomerulopathy. Curr. Diabetes Rev. 4, 39-45. 